(c) Group of authors, 2018

UDC 616.419

DOI - https://doi.org/10.14300/mnnc.2018.13102

ISSN - 2073-8137

\title{
BONE MARROW APLASIA IN A PATIENT TREATED WITH CEFOTAXIME
}

Dvoretsky L. I. ${ }^{1}$, Yakovlev S. V. ${ }^{1}$, Suvorova M. P. ${ }^{1}$, Sergeeva E. V. ${ }^{1}$, Zayratyants G. O. ${ }^{2}$

${ }^{1}$ I. M. Sechenov First Moscow State Medical University (Sechenov University),

Russian Federation

2 S. S. Yudin City Clinical Hospital, Moscow, Russian Federation

\section{АПААЗИЯ КОСТНОГО МОЗГА У БОАЬНОГО, ПОАУЧАВШЕГО АЕЧЕНИЕ ЦЕФОТАКСИМОМ}

\author{
А. И. Аворецкий ${ }^{1}$, С. В. Яковлев ${ }^{1}$, М. П. Суворова ' , Е. В. Сергеева ${ }^{1}$, Г. О. Зайратянц ${ }^{2}$ \\ 1 Первый Московский госуАарственный меАицинский университет \\ имени И. М. Сеченова (Сеченовский Университет), Российская ФеАерация \\ 2 Городская кАиническая больница им. С. С. ЮАина, Москва, Российская ФеАерация
}

Description of the first case of aplastic anemia caused by cefotaxime, a third-generation cephalosporin, with lethal outcome is presented. Clinical record of a patient and post-mortem examination results are given. Possible mechanisms of cytopenias induced by cephalosporin antibiotics are discussed.

Keywords: cephalosporin antibiotics, aplastic anemia, agranulocytosis

Представлено описание первого случая апластической анемии с фатальным исходом, вызванной цефалоспорином 3 поколения цефотаксимом. Приводится история болезни пациента и результаты патологоанатомического исследования. Обсуждаются возможные механизмы цитопений, индуцированных цефалоспориновыми антибиотиками.

Ключевые слова: цефалоспориновые антибиотики, апластическая анемия, агранулоцитоз

For citation: Dvoretsky L. I., Yakovlev S. V., Suvorova M. P., Sergeeva E. V., Zayratyants G. O. BONE MARROW APLASIA IN A PATIENT TREATED WITH CEFOTAXIME. Medical News of the North Caucasus. 2018;13(3):546-548.

DOI - https://doi.org/10.14300/mnnc.2018.13102

Для цитирования: Дворецкий Л. И., Яковлев С. В., Суворова М. П., Сергеева Е. В., Зайратянц Г. О. АПЛАЗИЯ КОСТНОГО МОЗГА У БОЛЬНОГО, ПОЛУЧАВШЕГО ЛЕЧЕНИЕ ЦЕФОТАКСИМОМ. МеДИЦИнСКИЙ вестник СеверноГО Кавказа. 2018;13(3):546-548. DOI - https://doi.org/10.14300/mnnc.2018.13102

AA - Aplastic Anemia

AC - Agranulocytosis

ADR - Adverse Drug Reactions
BM - Bone Marrow

CA - Cephalosporin Antibiotics

NSAID - Nonsteroid Antiinflamatory Drugs
0 ne of the adverse drug reactions (ADR) during the treatment with Cephalosporin antibiotics (CA) are various cytopenias (thrombocytopenias, neutropenias/agranulocytosis, hemolytic anemias and, less often, pancytopenias). Cephalosporininduced cytopenias can be based on two mechanisms - an immune and a myelotoxic one. Most publications on hematologic ADR in the course of treatment with CA, and ceftriaxone in particular, deal with the cases of neutropenias and agranulocytosis (AC) development. Analysis of these descriptions gives evidence of the possible (antibody-mediated) mechanism of ceftriaxone-induced $A C$ [1]. One of the reports analyzes 14 verified cases of ceftriaxoneinduced agranulocytosis. The main mechanism for the development of agranulocytosis is the immune mechanism, since in most cases there was no inhibition of erythropoiesis and thrombocytopoiesis [2]. However, bone marrow (BM) involvement was found in none of the cases, which was taken notice of in other - earlier - studies. Myelotoxic effect of $\beta$-Lactam antibiotics was discovered during the experimental studies in the course of in vitro granulopoiesis and monocytopoiesis cell culture, and along with this, a dose-dependent effect, most prominent with ceftriaxone and ceftazidime, was found [3].

In the analysis of cases of neutropenia caused by cephalosporin antibiotics (ceftaroline), the relationship between the duration of drug use and the frequency of neutropenia was established. The bone-marrow (BM) hemopoiesis picture was characterized by the absence of highly-differentiated granulocytic lineage cells, with the presence of numerous granulocyte progenitor cells 
[4]. In addition, a myelotoxic dose-dependent effect of penicillins and CA on granulopoiesis in vitro was recognized, which corresponded the dependence of neutropenia on a higher total antibiotic dose during a long-term therapy.

We observed a patient who developed aplastic anemia (AA) during the treatment with cefotaxime. The clinical observation follows.

Patient P., 79 y.o., was delivered to resuscitation and intensive care unit № 2 of S.S. Yudin City Clinical Hospital (Moscow) on 18.10.17 with the complaints about throatache and swallowing difficulty, body temperature risen up to $38^{\circ} \mathrm{C}$, loose stool and weakness. The patient fell ill two weeks before when throat-aches and hoarseness started to disturb him. He was diagnosed with pharyngolaryngitis and therefore put on cefotaxime i.m., and Hexoral and Furacilin topically, without effect. The temperature rose up to $38{ }^{\circ} \mathrm{C}$, hemorrhagic brash and loose stools appeared. On the day of hospitalization, the patient had a choking fit due to which he was hospitalized. Condition on admission is severe. The consciousness is clear, the patient is active. The skin is pale, warm and dry. Sporadic skin hemorrhages on the limbs. Small papules rash in the collar zone. Peripheral lymph nodes are not enlarged. Subcutaneous fat tissue is normally developed. Peripheral edemas are absent. Body temperature is $38.6{ }^{\circ} \mathrm{C}$. Meningeal symptoms are negative. The respiration rate per minute is 19 . Auscultation findings: harsh breathing, no rales in the lungs. The region of the heart is without changes. Heart borders are not extended. Muffled heart tones, irregular heart rhythm. No noises are auscultated. ECG: atrial fibrillation. Main artery pulse strength is satisfactory, arterial blood pressure is $98 / 63 \mathrm{~mm} \mathrm{Hg}$. Heart rate per minute is 115 . The tongue is pink, with white plaque. Mouth and tongue mucosae are ulcerated. The stomach is symmetrical, not bloated, soft and painless when palpated. The liver is not extended. The gall bladder is non-palpable. Peristaltic noises are common. Peritoneal symptoms are negative. Urination is voluntary. Pasternacki's sign is negative. The patient's condition was severe due to the systemic inflammatory response syndrome, metabolic disorders and water and electrolyte imbalance.

Complete blood count from 18.10.17: $\mathrm{Hb}-$ $72 \mathrm{~g} / \mathrm{L}$, erythrocytes $-2.54 \times 10^{12} / \mathrm{L}, \mathrm{MCH}-28.2 \mathrm{pg}$, thrombocytes - $77 \times 10^{9} / \mathrm{L}$, leucocytes - $0.5 \times 10^{9} / \mathrm{L}$, segmented cells - $18 \%$, lymphocytes - $58 \%$, monocytes - $24 \%$.

Bone marrow aspirate from 20.10.17: blasts - $2 \%$, promyelocytes $-1 \%$, neutrophilic myelocyte - $3 \%$, segmented neutrophils - $1 \%$, segmented eosinophils $23 \%$, lymphocytes $-60 \%$, plasma cells $-3 \%$, basophilic normoblasts - $5 \%$, indifferent cells - $2 \%$. Leuco/ erythro ratio - $18.6 \%$. Megakaryocytes in small amounts

Biochemical blood count from 18.10.17: total protein $47 \mathrm{~g} / \mathrm{L}$, creatinine - 245 $\mathrm{mmol} / \mathrm{L}$, total bilirubin $35.9 \mathrm{mmol} / \mathrm{L}$, CRP 184.0, ALT - $45 \mathrm{ME} / \mathrm{L}$. glycose - 7,1 $\mathrm{mmol} / \mathrm{L}$, sodium - $136.8 \mathrm{mmol} / \mathrm{L}$, potassium - $3.95 \mathrm{mmol} / \mathrm{L}$, lactate $-2.05 \mathrm{mmol} / \mathrm{L}$.

Microbiological blood test from 18.10.17 Escherichia coli, resistant to Ampicillin/Sulbactam, Cefepime, Ceftazidime and Ceftriaxone. Microbiological urine test from 19.10.17 Klebsiella pneumoniae (KOE $10^{3}$ ), resistant to Ampicillin/ Sulbactam, Cefepime, Ceftazidime, Ceftriaxone and Piperacillin/Tazobactam.

Peripheral blood tests were noted by a reduced amount of granulocytes up to 500 cells $/ \mathrm{mm}^{3}$ and lower, which agreed with the presence of AC. With account to concurrent normochromic anemia in the absence of reticulocytosis and thrombocytopenia, the most probable AC mechanism should be hemopoiesis depression. The bone marrow cytological screening revealed cellular depletion and considerable decrease of megakaryocyte amount, which, in the absence of blast cells, enabled to exclude acute leukemia and diagnose with AA.

The patient's state remained very severe. CT of thoracic organs diagnosed multisegmental pneumonia. Antibacterial therapy (Amoxiclav and Metronidazole) Noradrenaline, Sterofundin, Fragmin, Cordarone and erythrocyte transfusions were assigned, artificial lung ventilation was started. Despite the conducted therapy, the patient died on 20.10.17.

Clinical diagnosis. Main diagnosis: Drug-induced aplastic anemia.

Complications: community-acquired left-side pneumonia. Aphthous stomatitis. Necrotic enteropathy. Hemorrhagic syndrome. Hepatonephric insufficiency. Acute respiratory failure. Acute cardiovascular insufficiency. Pulmonary edema. Brain edema.

Patologo-anatomic diagnosis. Main diagnosis: aplastic anemia: bone marrow aplasia in flat and tubular bones. Complications: Sepsis, septicemia: Fibrinonecrotic pharyngolaryngitis. Aphthous stomatitis. Erosive gastroenterocolitis affecting gastric corpus, the whole empty intestine, ascending and transvers colons. Multiple organ failure syndrome: nephric, heart: myocardial lipidosis, pulmonary edema, bilateral hydrothorax ( $200 \mathrm{ml}$ on each side). Multiple petechiations in pia and pachymeninx, under the epicardium, pericardium, subpleural, in the retroperitoneal fat, in the empty intestine wall, in the urinary bladder mucous membrane and in the kidney pelvis fat tissue of both kidneys. Brain edema.

BM histology results (Figure) has shown: Lipocytes prevail in the bone marrow; the erythroid lineage is substantially narrowed and represented by sporadic small clusters with prevailing erythrokaryocytes. Sporadic granulocytes, small lymphocytes, separate plasma cells and siderophages are defined. Megakaryocytes are absent. Hemorrhage and sclerosis areas in the stroma.

Thus, hematologic condition of pancytopenia with related clinical signs (fever, hemorrhagic syndrome, aphthous stomatitis, enteropathy) together with the
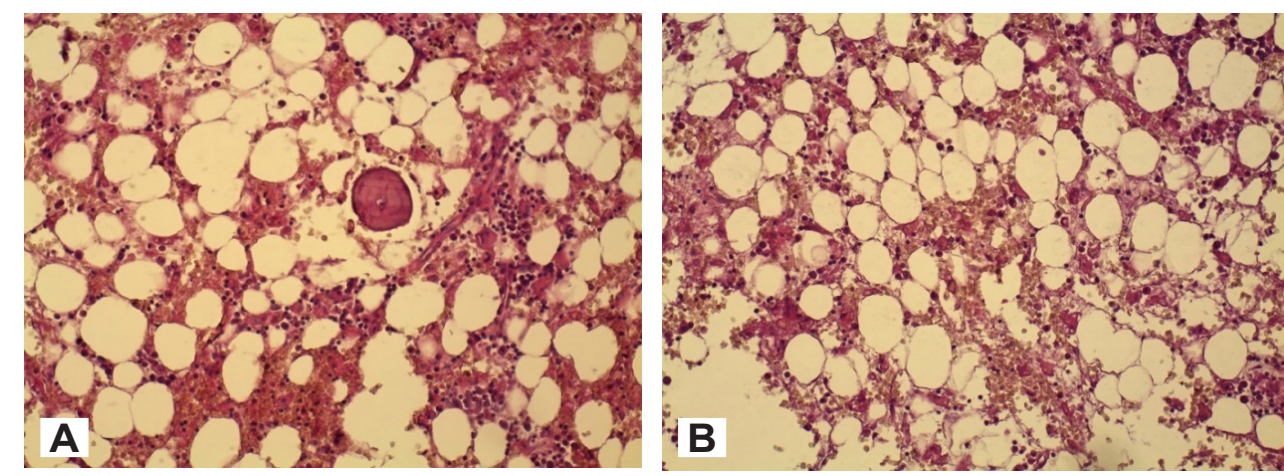

Fig. Bone marrow histology. Replacement of bone marrow tissue by fat cells was shown. Hematoxylin and Eosin staining, $\times 100$ 
bone marrow hemopoiesis depression and prevailing fat tissue in the BM (results of BM morphological examination) testified of the patient's having AA. Taking into account acute disease development, absence of anamnestic data about the peripheral blood changes in the past, appearance of clinical symptoms after taking cefotaxime with the absent indications for administering other drugs, cefotaxime should be considered the most probable ethiological agent of AA development. As an AA mechanism in the course of treatment by $C A$, one can assume the drug's depressant action on the pluripotent stem cell common for erythroid, granulocytic and thrombocytic hematopoietic lineages [5]. It can be supported by the data about depressing the activity of not only colony-forming units of granulocyte-macrophage progenitor cells, but also those of erythroid lineage in dogs that received high doses of cefazedone (a firstgeneration CA) for 4 months

In the literature we managed to find the description of the only one case of cefroxadine-induced (a secondgeneration CA) AA in a 50-year-old patient, who after seven days of urinary tract infection treatment with cefroxadine had a temperature rising up to $38^{\circ} \mathrm{C}$, with the $\mathrm{AC}$, anemia and thrombocytopenia found in the blood. The $\mathrm{BM}$ histology discovered rapid hemopoiesis depression and prevailing fat tissue, which was regarded as AA [6]. It is notable that this patient had a similar situation with AA development earlier, several years before the current episode, with the following hematopoietic regeneration. The authors are of the opinion that this case is the first description of AA in the course of treatment with CA. However, together with $\mathrm{CA}$, the patient received other drugs - NSAIDs and antihistamines in particular, which does not allow excluding their role in the AA development. Other three cases of $A A$ in the course of treatment with cephalexin are mentioned in unpublished messages of FDA while analyzing 11301 cases of various ADRs in the course of treatment with cefalexin. It should be noted that these patients did not do without concomitant treatment (NSAIDs and antihistamines) either, which makes the ethiological role of CA in the AA development ambiguous.

Conclusions. As we did not manage to find any publications about the cases of AA in the course of treatment with cefotaxime, it would be justified to consider our observation the first message about cefotaximeinduced AA. This observation confirms the necessity of hematological monitoring of patients receiving $C A$, especially upon the presence of pancytopenia, which requires a timely $\mathrm{BM}$ examination.

\section{Disclosures:}

The authors declare no conflict of interest.

\section{References}

1. Mariotti G., Caberlon S., Bertinato E., Podda G., Pugliano M. T. [et al.] Primary autoimmune neutropenia in adults: case report and review of the literature. Transfusion. 2014;54:2906-2910. https://doi.org/10.1111/trf.12711

2. Uy N., Thiagarajan P., Musher D. M. Cephalosporin side chain idiosyncrasies: a case report of ceftriaxoneinduced agranulocytosis and review of literature. Open Forum Infect. Dis. 2015;2(1):1-4. https://doi.org/10.1093/ofid/ofv007

3. Marie J. P. Antibiotics and hematopoiesis: toxicity of betalactam on in vitro granulopoiesis. Pathol. Biol. (Paris). 1987;35(10Pt2):1408-1411.
4. Phull P., Lerner A. Agranulocytosis Secondary to Ceftaroline Use: A Case Report and Review of the Literature. Journal of Hematology. 2016;5(3):103-105. https://doi.org/10.14740/jh281w

5. Al Qahtani S. A. Drug-induced megaloblastic, aplastic, and hemolytic anemias: current concepts of pathophysiology and treatment. Int. J. Clin. Exp. Med. 2018;11(6):55015512.

6. Han J., Lee H., Hyojeong H., Lee Y. S., Yun-Jeong B. [et al.] Cephalosporin-induced recurrent aplastic anemia. Eur. J. Clin. Pharmacol. 2011;67:317-318. https://doi.org/10.1007/s00228-010-0913-3

\section{About authors:}

Dvoretsky Leonid, MD, DMSc, Professor, Head of the chair of internal medicine № 2; e-mail: dvoretski@mail.ru Yakovlev Sergei, MD, DMSc, Professor of the chair of internal medicine № 2; e-mail: antimikrobe@yandex.ru Suvorova Margarita, MD, CMSc, Assistant of Professor of the chair of internal medicine № 2; e-mail: antimikrobe@yandex.ru Sergeeva Elena, MD, CMSc, Assistant of Professor of the chair of internal medicine № 2; e-mail: alnic55@mail.ru Zayratyants Georgii, MD, CMSc, Head of pathology-anatomic department; e-mail: goshaz@mail.ru 